\title{
Denagliptin Tosylate
}

National Cancer Institute

\section{Source}

National Cancer Institute. Denagliptin Tosylate. NCI Thesaurus. Code C72735.

The tosylate salt form of denag liptin, a potent, selective, orally bioavailable,

fluoropyrrolidine-based inhibitor of dipeptidyl peptidase 4 (DPP-4), with hypoglycemic activity. 